\title{
On Gender Inequality and Life Satisfaction: Does Discrimination Matter?
}

\author{
Christian Bjørnskov $^{\S}$, Axel Dreher ${ }^{\ddagger}$ and Justina A.V. Fischer ${ }^{\dagger}$
}

\section{SSE/EFI Working Paper Series in Economics and Finance No. 657,}

April 2007, final version

\begin{abstract}
This paper analyzes the impact of gender discrimination on individual life satisfaction using a cross-section of 66 countries. We employ measures of discrimination of women in the economy, in politics, and in society more generally. According to our results, discrimination in politics is important to individual well-being. Overall, men and women are more satisfied with their lives when societies become more equal. Disaggregated analysis suggests that our results for men are driven by the effect of equality on men with middle and high incomes, and those on the political left. To the contrary, women are more satisfied with increasing equality independent of income and political ideology. Equality in economic and family matters does overall not affect life satisfaction. However, women are more satisfied with their lives when discriminatory practices have been less prevalent in the economy 20 years ago.
\end{abstract}

Keywords: Gender gap, happiness, well-being, discrimination, life satisfaction JEL-Codes: I31, J16

Acknowledgement: We thank participants of the First World Meeting of the Public Choice Societies in Amsterdam for helpful comments. The third author acknowledges financial support from the Swiss National Science Foundation (SNF).

\footnotetext{
$\S$ Aarhus School of Business, Department of Economics, Prismet, Silkeborgvej 2, DK - 8000 Aarhus C, Denmark; E-mail: ChBj@asb.dk.

${ }^{\ddagger}$ ETH Zurich, KOF Swiss Economic Institute, Weinbergstrasse 35, CH-8092 Zurich, Switzerland and CESifo, Germany; E-mail: mail@axel-dreher.de.

$\dagger$ Department of Economics, Stockholm School of Economics, P.O. Box 6501, SE-113 83 Stockholm, Sweden. E-mail: justina.fischer@hhs.se
} 


\section{Introduction}

Equal political and economic rights of women are viewed to be among the major achievements of the $20^{\text {th }}$ century, yet social reality often lags behind. During the last century, many governments around the world seem to have adopted 'modern' laws without the intention to rigorously enforce them - they talk the talk without walking the walk. This reluctance of traditional societies to 'modernize' is often explained by their rejection of 'Western' values that are perceived as instrumentalized to sustain US American and European political dominance and are thus alien to and superimposed on the indigenous culture (Huntington, 1993). On the other hand, feminists tend to view ongoing discrimination of women in both traditional and developed countries as an effort of men to defend their privileges such as higher social status and better employment possibilities. But even if such causes of intentional discrimination would have been eliminated, so-called 'statistical discrimination' caused by information asymmetries might persist when missing or unobservable information on women is replaced by characteristics of the average woman.

Clearly, the common view assumes a zero-sum game so that through improved gender equality women gain, while men lose. Given that the constraints women faced in the past and still face today - often depended on their social status, women's gains from greater equality might be unequally distributed across social groups (e.g. Patessio, 2006). Moreover, as persons with a rightist view are assumed to be more in favor of a conservative societal role than a leftist person, re-defining women's role in society should be opposed by the first but supported by the latter, according to the stereotype. As political economists, we relate agreement and disagreement, gains and losses to subjective well-being; the closer the social reality is to one's preferences, the higher individual happiness/utility should be. We ask whether men are really happier in societies where women's rights are suppressed, and whether women are really less satisfied.

More specifically, we investigate whether and to what extent common views and prejudices about the impact of discrimination on well-being hold when tested against real life data. We therefore analyze how life satisfaction of women and men across 66 countries are influenced by effective gender equality in the economy, in politics, and with respect to family relations. ${ }^{1}$ As the impact of social/societal conditions might depend on one's view of the world or one's financial constraints, we also look at men and women separately, not only at entire gender-specific populations but also grouped according to political orientation and income. Because of the path dependence of the unfolding of human life, gender inequality in

\footnotetext{
${ }^{1}$ Psychologists have carried out few small sample studies on the effect of 'career' discrimination on women, ususally finding well-being to decrease (see e.g. Foster et al., 2004, Schmitt et al., 2002 for literature).
} 
the early eighties might equally affect today's opportunities, choices and aspiration levels even to a stronger degree than the current situation. As such, we not only investigate the impact of past discrimination, but also the effect of changes in the level of discrimination over the last 20 years.

To anticipate our main results, we find that men and women are more satisfied with their lives in societies with increasing equality in political opportunities and participation over the previous 20 years. Disaggregated analysis suggests that our results for men are driven by the effect of increasing equality on men with middle and high income, and those on the political left. To the contrary, women are more satisfied with increasing equality independent of income and political ideology. Equality in economic and social matters does overall not affect life satisfaction. However, women are more satisfied with their lives when there has been less discrimination in the economy 20 years ago.

The remaining sections are organized as follows. Section 2 develops our hypotheses, while section 3 introduces the data, and in particular our measures of discrimination. Section 4 describes the method of estimation. Section 5 presents the results; the final section concludes.

\section{Theoretical considerations}

In mainstream economics there is a long tradition of neglecting female contributions to societal well-being. Already with Adam Smith's work "The wealth of nations," goods that were not traded over markets but remained within the realm of the single household used not to belong to the subject matter of economic analysis (see Shah, 2006). But, traditionally, it is those goods that are created and consumed within the "identical household" that are produced by its female members. Only when women started producing for strangers, or when the share of women in permanent employment outside the household rose, did female work and female pay become part of economic investigation (Goldin, 2006). It needed further societal development in the 1870 s to generate awareness of political - and later during the 1960s of economic - gender inequality (see the seminal contribution of Becker, 1957/1971). Formal theoretical treatments of this issue, particularly of their effects on well-being, nevertheless remain rare in the economics literature. In the following, we outline a simple theoretical framework in which to evaluate the possible labor market and, finally, welfare outcomes of easing gender discrimination, and develop a set of hypotheses to be tested in the proceeding sections. 
From a theoretical viewpoint, one of multiple ways to look at gender discrimination is to focus on the leisure/work optimization process assumed in standard economic models. Both women and men make choices of how to allocate their time and efforts under certain constraints in order to maximize their utility, and possibly also dynastic utility of their families. One of the potential impacts of gender discrimination is to tighten these constraints that can result in either positive or negative welfare effects. As an example of a negative effect, by excluding one social group from specific types of occupations, the trade-off between labor market participation and staying at home is biased towards home work, resulting in placing a disproportionate part of the burden of necessary home work - child care, cleaning, doing the laundry etc. - on them. In consequence, discriminated individuals will be forced to allocate their time and resources suboptimally compared to a situation without discrimination. At first, in application to gender discrimination, the latter type of discrimination could be expected to lead to an improvement of the life satisfaction of men, the preferred group, as some of the burden of home production is lifted from their shoulders.

However, if home production is a sufficiently good substitute for wage employment, holding the family budget constraint relatively constant will imply that the unconstrained wage earners will have to work harder in their chosen occupations than would be the case if discriminatory practices did not limit the other group's choices - in particular if the constraints faced lead to either non-occupation or only stereotyped job choices. The preferred group may therefore often be forced to make suboptimal occupational choices due to discrimination against the other group. ${ }^{2}$ Again applying these thoughts to gender discrimination, under such conditions, the subjective well-being of men may also suffer from discrimination of women.

On the other hand, an individual's labor market choices and their welfare effects are probably evaluated relative to what is perceived as relevant alternatives. As such, stereotyping may exert an alleviating influence on the otherwise deleterious effects of discrimination because it effectively limits the set of alternative choices that an individual, man or woman, includes as relevant comparisons (Foster et al., 2004). Even in the context of discriminatory practices, adaptation effects of life satisfaction can therefore pertain to make objectively inferior situations of limited significance (cf. Irwin, 1944). Given this type of adaptation of individual behavior and relevant social norms, discriminatory practices may in the longer run not matter to most individuals, although changes in such practices could still affect subjective well-being.

\footnotetext{
${ }^{2}$ This argument assumes that labor markets are still competitive insofar that the preferred group cannot extract monopoly rents that might compensate for the loss (see also Becker 1957).
} 
There is, however, an important point to note when taking this theoretical view. As always, the constraints induced by discrimination may not be binding to everyone, i.e. the optimal choices without these constraints of some individuals may lie within the space spanned by the discriminatory constraints. If this is so, gender discrimination at best exerts no direct effect on the life satisfaction of such individuals. We specifically stress that this is a best-case scenario because these individuals - that are presumably most often men, but whom we henceforth term Type I - may be hurt by the indirect impact of discrimination through externalities exerted on them by the (altered) behavior of those who are directly affected by it. The latter we term Type II (which are presumably mostly women), were the ones for which constraints were previously binding and who alter their behavior when discriminatory constraints are eased.

For example, if easing constraints of discrimination implies that more people of Type II enter a segment of the labor market previously occupied exclusively by Type I, competition increases and drives down the relative wage and social status associated with these jobs within this segment. In turn, this will decrease the life satisfaction of Type I individuals while it probably increases that of Type II.

Yet, if Type II individuals have formed their expectations of wages and status without internalizing the effects of increased competition induced by lifting discriminatory constraints, their life satisfaction may not increase (or increase very little) while their behavior harms Type I people. This could be the case for both men and women of both types to the extent that they, for example, face direct competition from the other 'type' in the labor market. It should nevertheless be noted that in most standard settings this would be more likely for women than for men.

Furthermore, for Type I individuals who are bound by their previous choices when constraints are lifted, the behavior of the rest of society may induce another type of negative externality on them. For example, for women who have chosen to be non-working spouses in the past, lifting constraints on female employment in the present could potentially have the effect that their social life suffers as less and less women will be in the same position as they are, and, e.g. opportunities for social interactions during normal working hours decrease. When easing discriminatory constraints, social norms may change accordingly and the value of inactive women in society might depreciate. In Scandinavian countries, for example, where most women are in the official labor market, those who choose to stay at home to take care of their children are often frowned upon and consequently suffer to some degree from being socially ostracized. Put simply, social norms may have been altered by the changes in gender 
discrimination, ${ }^{3}$ which may impose new but different constraints on the current choices and thus life satisfaction of those who had made their choices within the space spanned by past discriminatory constraints. As such, we can only draw very broad theoretical implications.

Turning to gender-specific subjective well-being, we now note how our general theoretical considerations can be applied in a commonsensical way. At first sight, discrimination of one gender automatically seems to imply a preference for the other. Thus, with respect to men, in societies characterized by discrimination of women, men as 'exploiters' are thought to profit, enjoying various advantages in many fields of society. For example, men might have better access to education and health care, higher social status, being attributed 'natural' authority and leader characteristics, increasing their advantage over female competitors in the labor market and contributing to better employment opportunities (e.g. Schilt, 2006). In the context of our formal theoretical considerations, the discriminatory constraints faced by most men may not be binding, i.e. they behave exclusively as Type I individuals. However, given that they are binding for most women who thus tend to belong to Type II, men might therefore also indirectly profit from discrimination of women in society by their economic exploitation as cheap - since comparably underpaid - labor force. Consistent with this view, Busse and Spielmann (2006) report unequal wages to lead to a comparative advantage in international trade in case the production of the traded good is (female) labor intensive. Given that the vast majority of investors and managers are male, according to this view it is the other half of the population rather than the female workers who reaps the profit from this exchange. In addition, Siegel (2006) reports that discrimination of women in the labor market biases the trade-off between female employment and provision of health care at home, disfavoring employment. As such, male dominance in the fields of politics and industry helps establish and possibly also maintain institutional and organizational frameworks that preserve existing gender inequalities (e.g., Buswell and Jenkins, 1994; Kim, 1989). ${ }^{4}$

Discrimination in education and access to health care also has direct implications for female health state and longevity, child mortality, and future employment possibilities, ${ }^{5}$ but (expected) discrimination in the labor market, in turn, affects human capital investment

\footnotetext{
${ }^{3}$ For simplicity, we assume here that a change in discriminatory practices affects social norms and values. However, it might well be that it is the alteration in norms that triggers and thus manifests itself in a change in gender discrimination.

${ }^{4}$ As Blankenship (1993) shows for the US, even employment antidiscrimination policies such as the Equal Pay Act of 1963 and Title VII of the Civil Rights Act of 1964 might serve to maintain discriminatory practices.

${ }^{5}$ For the relation between pre-natal health care and child health status see, e.g., Choi and Lee (2006).
} 
decisions of women or her family. ${ }^{6}$ Moreover, the employment situation of women spills over to other societal areas such as decision-making within the family, pension and welfare payment entitlements, access to credit, division of labor within the household, etc. In fact, Browne and Stears (2005) found that resource inequality explains existing inequalities between genders better than, for example, the capabilities approach of Sen (1999). In a pertinent example from a developing country, Pitt et al. (2006) show that the autonomy of women in family issues rises with the size of micro loans received, while non-employment today implies less current but also future support from welfare and pension systems. However, even in developed countries, the so-called 'modern' or 'reformed' pension systems - based on individual entitlements only - systematically discriminate female life courses with their natural gaps in employment history (Turner et al., 2006). Given that the negative externalities exerted by what we have called Type I individuals (primarily men) are small, we arrive at a first testable hypothesis.

Hypothesis 1: Gender equality increases well-being of women but decreases that of men.

However, as our potential counterargument goes, discrimination of women in the labor market might impede sufficient diversification of income sources for the family as risk insurance against labor market shocks. Similarly, restricted access of women to education and health care, both of which aim to secure productivity of women in the labor market, may also be deleterious to men's well-being due to the externalities described above. In addition to the purely economic effects of discrimination, men as primary providers of household income are likely to experience substantially more psychological stress in a more discriminatory society that keeps financial contributions of women from diversifying household income. Moreover, segregation of the labor market arguably increases gender-specific labor supply within its segments over and above what would be optimal, impeding employment and self-selection based on comparative advantage. A counterhypothesis under the condition that Type I individuals (primarily men) are harmed by the behavior of Type II individuals (primarily women) induced by discrimination therefore is:

Hypothesis 2: Gender equality increases well-being of men and women.

\footnotetext{
${ }^{6}$ Neumark and McLennan (1995) analyze the impact of gender discrimination on labor market outcomes. For an interesting meta analysis of the gender gap in wages see Stanley and Jarrell (1998).
} 
On the other hand, there might well be situations in which discrimination is, on average, beneficial to some groups in society. ${ }^{7}$ Arguably, men and women in different societal groups may be affected to different degrees, as already noted in the introduction, since discriminatory constraints may either not be binding or constraints may be more or less strictly binding for some groups than for others. Persons with an affluent family background, for example, do not financially depend on employment opportunities in the labor market or limited access to credit. Rather, employment may instead be sought for its procedural utility mainly, and in case access to the labor market is restricted, other types of voluntary activities serve as more or less imperfect substitutes. As one example, until 1940 even in the US major shares of employed married women came from lower class backgrounds, thus suggesting that employment was a bare necessity (Goldin, 2006).

Moreover, as Wellington (2006) shows, particularly highly educated women - but possibly all wealthy persons - have the capability of setting up their own business, making them more independent from existing labor market frictions. Such relations between female education and self-employment might be historically deeply rooted, going back to the managerial obligations of upper class women in the middle ages (see e.g. Goto, 2006, for Japan). Equally, financial nest eggs increase individuals' independence from limited/discriminatory access to public resources of education or health care or even government policies as suggested in Bjørnskov, Dreher and Fischer (2007). In light of our theoretical considerations, women in the high-income group are more likely to be of Type I since discriminatory constraints are not necessarily binding.

Hypothesis 3: Gender equality is likely to exert no impact on people with high-income.

Therefore, there is reason to doubt that the subjective well-being of men or women with high incomes is affected by discrimination to the same degree as that of people with average or low incomes for which discriminatory constraints may be more likely to be binding. Yet, it should be stressed that the distinction between people with middle and high income, on the

\footnotetext{
${ }^{7}$ As one example, Neumark and Stock (2006) have shown that the introduction of equalizing laws leads to a decline in employment of women. In other words, unequal payment made female labor relatively cheaper compared to male labor, leading to excess demand. In addition, discrimination might restrict occupational choices of men to traditional, but low-paid professions, allowing women to choose 'modern' professions with a higher return (Munshi and Rosenzweig, 2006). Moreover, assuming discriminatory gender-specific characteristics might be beneficial for women in some cases in which 'male' characteristics are viewed as destructive. For example, female offenders were found to receive more lenient punishment (Rodriguez et al., 2006). Even psychologically, existing discrimination might be anticipated, leading to lower aspiration levels and gender-biased preferences, so that women are usually found to be happy with their jobs although they are systematically underpaid (Hakim, 1991; Theodossiou, 1998). Finally, gender inequality in various fields of society may constrain women's choice set, lowering their costs of decision-making.
} 
one hand, and those with low and middle income, on the other hand, can be quite artificial, in particular when compared across several dissimilar countries. In consequence, it is unclear whether a middle-ranged family income is sufficiently large to (a) compensate for the negative financial effects of non-participation of women in the labor market, and (b) make women's decision for education or self-employment insensitive to the household's financial situation. We nevertheless hypothesize that:

Hypothesis 4: Gender equality increases well-being of people with low-income.

On a more normative level, it is also possible to make a case for distinguishing between moral and political convictions. Traditionally, persons with a leftist orientation are believed to be in favor of egalitarian equality, a concept going back to the French revolution. Rooted in workers' fight for a 'fair' share in firm owners' profits, 'equal pay for equal work' became a well-known leftist slogan. The radical proletarian suffragette movement of the late $19^{\text {th }}$ century gained more support from left and far-left parties than from groups with a more conservative ideology (cf. Encyclopedia Britannica). ${ }^{8}$ Likewise, many discriminatory practices, particularly those pertaining to education, politics, and the labor market are deeply rooted in traditional gender roles. According to such roles, women are caring, assisting persons, but not capable of leadership or decision-making abilities in issues not directly related to the household. Based on such views, typical female employment is found in the health, education, administration and service sectors, but even in these fields rarely in leading positions that require 'natural authority'?

Consequently, from the conservative viewpoint, the level of female education needed and achieved is an average one, and preferred engagement of women in politics takes place, if at all, at the local level. Clearly, this traditional role model and its derived social norms more or less coincide with what non-traditionalists would call 'discriminatory practices'. As the origins of politically diverse attitudes towards gender equality are historically rooted and thus seem to have changed little over the years, we therefore conjecture that in line with the formal theoretical considerations, the gap between social norms created by less discrimination and the set of relevant options outlined by prevailing social norms linked to political ideology is smaller for people of a general leftwing conviction, as they hold less discriminatory views on

\footnotetext{
${ }^{8}$ Women's rights advocates also fought for what we would nowadays call 'antidiscriminatory practices' in basically all fields of society (education, property rights, family law). Bourgeois feminists tended to make equal claims, but are said not to have really questioned the patriarchal society.

${ }^{9}$ A classic example are schools, in which most of the teaching personnel is female, but the superintendent male. This pattern still persists (Mertz, 2006).
} 
gender roles. Even though this also implies that a group with 'modern' social norms may implicitly discriminate against other groups abiding by traditional norms, this leads us to the last of our directly testable hypotheses:

Hypothesis 5: Gender equality increases well-being of people with leftwing political conviction.

As such, the five hypotheses outlined here can be directly tested against life satisfaction data. We nevertheless need to emphasize that our theoretical considerations do not lead to one-sided expectations, as all depend on the sum of the ultimate effects of gender constraints, stereotyping and possible negative externalities.

\section{Data}

We employ three measures of women's discrimination in the fields of politics, business and economy, and social relations, obtained from the widely-used Cingranelli-Richards (CIRI) human rights database (www.humanrightsdata.org), which is based on various US State Department Country Reports on Human Rights Practices and annual reports from Amnesty International. In general, it is important to note that these indicators of women's rights are exclusively concerned with the human rights practices of governments. Human rights practices are the human rights-related actions of a government and any and all of its agents, such as police or paramilitary forces. [....] [In contrast], a country's human rights policies are what a government says it is going to do to ensure the protection of the human rights of its citizens' [laid down in] constitutional provisions or legislation protecting human rights, but this is irrelevant to our evaluation of actual government human rights practices which often diverge from policies." (Cingranelli and Richards, 2004, p. 5). In other words, the indices reflect societal reality rather than theoretically existing conditions.

The first measure, women's political rights, includes the active and passive right to vote, to party membership, to government positions, and to petition. This index ranges from 0 (no political rights by law) to 3 (legally guaranteed rights and effective political influence in governing bodies). For more detailed information, see Table A1 in the Appendix.

The second measure pertains to the sphere of economics and business. The women's economic rights index measures equality in payment, hiring and promotion practices, freedom of professional choice and working hours, job security, and protection against sexual harassment. The index is zero if women have no legally stipulated right to economic 
participation and are not protected against discriminatory practices. The highest value of 3 is achieved if women's rights are not only legally protected, but also vigorously enforced by the government (see also Table A2). ${ }^{10}$

Finally, the third measure reflects women's social rights in society. It is the broadest measure among the three as it covers many different areas of social relations. Specifically, it relates to inheritance, marriage and divorce, mobility and residence, within-family property rights, social activities at the local level, education, and sexual self-determination (see also Table A3). Issues this measure does not capture include domestic violence, trafficking and prostitution, sexual harassment, honor killings, dowry deaths, and rape. Again, the index takes on values between 0 and 3 , with 3 being achieved if legal stipulation, a high level of enforcement and anti-discrimination practices coincide.

An advantage of the CIRI database is that it measures discrimination for each year and thus allows comparisons not only across countries but also over time. Exploiting this variation, we construct indicators capturing the change in equality between two different points in time, namely between 1999-2000 and 1980-1985, of which the first is roughly contemporaneous with the collection of the life satisfaction data (as introduced below). To gauge the impact of past levels of discrimination we construct averages for the early eighties (1980-1985).

All individual-level variables in our model are derived from the $3^{\text {rd }}$ and the $4^{\text {th }}$ waves (1997-2000) of the WVS. ${ }^{11}$ Our dependent variable, self-reported life satisfaction, is measured on a ten-point scale ranging from 1 (completely dissatisfied) to 10 (completely satisfied). Societal groups are categorized by either self-reported income levels (low, middle, and high), gender, or political orientation. The full data sample contains about 66,000 individuals, which is roughly divided in half by gender and drops to about 15,000 when dividing the sample according to gender-specific ideology or income groups. Observations with no specific political orientation have been excluded.

In the following, we employ a model that also includes variables aggregated at the country level. Most of these country characteristics are obtained from widely-used international data bases provided or administered by the World Bank, the IMF and the UN (see Bjørnskov, Dreher and Fischer (in press) for details). Table 1 shows the measures of discrimination used to test the hypotheses formulated above and their sources, while Table A2 in the Appendix provides descriptive statistics.

\footnotetext{
${ }^{10}$ It should be noted that most of these components pertain to wage-employment, not to self-employment.

${ }^{11}$ Most of the interviews were conducted between 1999 and 2001. Only approximately 13'000 interviews out of 61'000 were taken in 1997.
} 


\section{Method}

In order to analyze the impact of discriminatory practices on individual life satisfaction, we combine aggregate factors with individual-level determinants in one model. First, the individual-level determinants are based on model specifications utilized in contemporary happiness research (e.g. Ferrer-i-Carbonell, 2005; Dorn et al., 2006). They comprise variables such as age, gender, occupational status, marital status, education, income, political orientation, religious denomination and frequency of service participation, and horizontal and vertical trust. Second, various contributions have shown that certain national characteristics equally influence individual well-being, which we account for by the inclusion of aggregate variables. In particular, we add an array of aggregate factors which we have shown to be robust and influential predictors of individual life satisfaction, as described in Bjørnskov, Dreher and Fischer (in press). These country-level variables include measures of economic well-being (infant mortality, openness to trade, business climate), cultural factors (share of Catholics or Protestants, a dummy for post-communist countries, geographic region), and political determinants (bicameralism, years of independence).

The models are estimated by ordered probit, with standard errors clustered by countries to account for within group correlation (Moulton, 1990). Similarly to the approach taken in the growth literature, the impact of an improvement in gender equality may be the larger the less equal a society initially was, reflecting decreasing marginal utility of improving social conditions. Therefore, we expect well-being to be affected by changes in inequality conditional on the initial level, which thereby also allows for the potential effects of path dependence and long-run adaptation effects.

Specifically, life satisfaction is a function of the initial level of gender equality $D$ in country $s$, the changes in gender equality over the twenty year period $\Delta D$, and a vector $M$ containing the aggregate and individual control variables for person $j$ in country $s$. More specifically, we determine the probability of observing a particular level of subjective wellbeing by the probability that an underlying score is within the range of two particular cut points $k_{i-l}$ and $k_{i}$ for the estimated outcome $i$ (life satisfaction level $i$ of individual $j$ in country $s)$. This score is obtained by estimating a linear function of the independent variables in $D$ and $M$ plus a random error $u$. As such, we estimate the probability that individual $j$ reports a level of life-satisfaction $i$ in cross-sectional regressions for more than 60'000 individuals in a maximum of 66 countries: 


$$
\operatorname{Pr}(\text { outcome }=i)=\operatorname{Pr}\left(k_{i-1}<\beta^{\prime} M+a D+\mathrm{b} \Delta \mathrm{D}+u \leq k_{i}\right) .
$$

For all regressions, we report both coefficients and marginal effects of the variable of interest, the number of observations and countries included, and McFadden's R squared (denoted 'Pseudo R2') as goodness of fit measure of our model. ${ }^{12}$ Based on the estimates, marginal effects are calculated for the probability of reporting the highest level of life satisfaction, evaluated at the sample mean. The next section presents the results.

\section{Results}

For the sake of simplicity, the following outcome tables only report the effects of our equality measures that are added to the baseline model. The baseline variables listed in Table A1 in the Appendix are included in all regressions, but not shown. Specifically, we report the coefficient estimate on the change in gender equality between the early eighties and the year the WVS survey was carried out (1999-2000), and the coefficient pertaining to the level measured in 1980-1985, as well as their marginal effects.

The results for the full baseline model for the whole population are displayed in the Appendix (Table A1). They show that most of the individual-level determinants such as age, gender, marital status, occupational status, etc. exert influences similar to those reported in the previous empirical happiness literature (e.g. Frey and Stutzer, 2000; Ferrer-i-Carbonell, 2005). An in-depth discussion of the impact of these country characteristics such as the political institutions, government spending, trade and business, geographic location, majority religion and a country's past, is provided in Bjørnskov, Dreher and Fischer (in press), reporting broadly consistent results. The following sections show how discrimination affects well-being. Tables 1-3 focus on the whole population and also analyzes men and women separately. In Tables 4-9 we test whether our results depend on individuals' income situations or political orientations.

\section{A. Results for the whole population, men and women}

Table 1 focuses on the impact of economic discrimination on well-being. According to the results, neither the initial level of economic discrimination nor changes over the last 20 years significantly affect well-being of the whole population or that of men. However, less discrimination about 20 years ago increases well-being of women today (while changes in the

\footnotetext{
${ }^{12}$ In general, a Pseudo R2 of about 0.06 is obtained in individual-level life satisfaction analyses (Dorn et al., 2006).
} 
level have no impact), possibly indicating the path dependence of professional careers. Obviously, what may matter for well-being today is not current discrimination but discrimination at the time when educational and professional choices were made under the then prevailing constraints. As such, the impact of gender disparity in the labor market on happiness of women rather than men is consistent with theory. Yet, whether the effect on women is due to real or perceived constraints is open for discussion. Goldin (2006), for example, claims discrimination in the labor market to matter for women through its psychological impact only insofar as the professional career positively contributes to female identity and thus life satisfaction. However, as long as women choose non-permanent and transitory employment like a Stackelberg-follower under the constraint of her husband's labor supply decision, less discrimination of women is not likely to affect the life satisfaction of men. As such, in this situation men in general avoid negative externalities.

Insert Table 1 about here

Table 2 replicates the analysis for discrimination in politics. As can be seen, improved gender equality over the period 1980-2000 increases the well-being of men and women likewise, at least at the five percent level of significance. Not surprisingly, the gains for women exceed those for men, with marginal effects double in size $(0.048$ versus 0.023$)$. The regression outcomes show that initial gender equality also matters. While the coefficient is significant in the sample focusing on women and in the overall sample, there is no significant effect on the well-being of men. Overall, these results suggest that discrimination in politics reduces life satisfaction - but more so for women than for men.

As regards gender equality in politics, changes as well as past levels equally appear to raise life-satisfaction, with a stronger impact on women than on men. Following the recent happiness literature on political institutions, a stronger participation of women in politics may shift policy-making towards a more women-oriented point in the policy spectrum, affecting present policy outcomes (Fischer and Rodríguez, 2007). In this light, it is noteworthy that men also benefit from these societal changes, which necessarily means that discrimination against women in general implies negative externalities borne by men. 
Turning to gender equality in the social sphere, Table 3 shows that discrimination - be it past levels or improvements over time - does not seem to matter for life satisfaction, with all coefficients being completely insignificant. This result might be caused by mutual cancellation of both positive and negative effects of discrimination on well-being. Alternatively, the result may equally reflect that changes or cross-national differences in gender equality are irrelevant in explaining worldwide variation in individual life satisfaction due to a very fast adaptation to new societal circumstances as is a standard finding in other parts of the life satisfaction literature (cf. Lykken and Tellegen, 1996).

Insert Table 3 about here

To provide a short summary, gender equality in politics appears to be conducive to the life satisfaction of both men and women (supporting hypothesis 2), while less discrimination in economics and business is only conducive to that of women. Conversely, the results suggest that equality in the social sphere is not important for life satisfaction.

Path dependence implies that today's choice set is determined and restricted by decisions made at preceding points in time in which different discriminatory circumstances and social norms did constrain choices. As a consequence, discrimination in the past might well exert an impact on today's individual consumption possibilities, affecting present wellbeing. Our analysis identified such path dependencies for (a) men and women with respect to gender equality in political participation and (b) women with respect to the economic sphere. However, diminishing discrimination in the political area over time was equally found to play an important role for subjective well-being. More specifically, more effective participation of women in politics appeared conducive to peoples' happiness, both of men and women equally. $^{13}$

\footnotetext{
${ }^{13}$ It is noteworthy that in these cases an additional and simultaneous path dependence effect was identified, indicating that both changes over time as well as past levels of discrimination matter for subjective well-being.
} 


\section{B. Results by income and political ideology}

The general results thus support the existence of differential effects of gender inequality. However, both constraints and social norms may differ across income groups or ideology. Tables $4-9$ therefore replicate the results for the gender-specific samples split according to income (low/middle/high) and political ideology (left/right). With respect to gender equality in the economy (Table 4), diminishing disparity over the last 20 years does not significantly affect the well-being of men, while less discrimination measured in 1980 is beneficial for leftwing oriented men. Note, however, that there is no significant effect in any sample split by income, contradicting our expectation that improved employment opportunities of women may relax households' budget constraints.

Mirroring the findings for all women (Table 1), we find changes in discrimination in business and economics over the last 20 years to be irrelevant to all women likewise (Table 5), while gender equality 20 years ago is conducive to the well-being of women according to most subgroups, possibly indicating a strong path dependence of professional careers. Not surprisingly - and in line with our expectations - the largest path dependence effect prevails in the low-income group, for whom gender specific constraints have probably been most binding. Women in the high income group are not affected by discriminatory practices in the labor market, again supporting our predictions.

Insert Tables 4 and 5 about here

Turning to the results for discrimination in politics (Tables 6 and 7), we find gender equality in the past not to matter for the life satisfaction of men, while changes between the years 1980 and 2000 increase the well-being of men in some sub-groups. In particular, as predicted, leftist oriented men seemingly gain from such development (at the 5 percent level of significance), in contrast to those on the political right, whose well-being is not significantly affected. Moreover, improvements from 1980 on are conducive to the utility of men in the middle and high income group equally, contrasting the insignificant effect in the low income group.

In line with our expectations and corroborating the results for women in the entire sample (Table 2), diminishing gender disparity in political participation raises the welfare of women in all subgroups, be it in form of changes over time or, for most groups, measured as past levels in 1980. The latter effect is not observable in the high income group, suggesting 
that the well-being of these women is independent from shifts in policy outcomes, which is in line with our expectations. In general, the benefits for people with low income are statistically weaker and smaller in size compared to the middle income group. On the other hand, there is a considerable difference in magnitude of the impact between left-wing and right-wing women $(0.039$ versus 0.062$)$.

Insert Tables 6 and 7 about here

Mirroring the estimation outcomes for women and men reported in Table 3, improved gender equality in the sphere of social relations is not related to well-being in the various gender subsamples by political ideology or income level (Tables 8 and 9). As sole exception and somewhat in support of hypothesis 4, a stronger position of women relative to that of men in their past social relations exerts a beneficial impact on women with low income (at the 5 percent level of significance).

Insert Tables 8 and 9 about here

Summarizing, the results for the gender-specific subsamples by ideology and income often confirm what has been observed for the entire samples of men and women. However, comparing the life satisfaction outcomes for the three indicators of discrimination across subgroups, systematic patterns along ideology and income can be identified.

First, we find support for our hypothesis 5 that equal opportunities for women are in relatively stronger congruence with a leftist ideology that is probably critical of traditional gender role models and the related social norms. As such, left-wing oriented people appear to have benefited relatively more from less discrimination than did persons with a conservative ideology. Overall, greater gender equality in economics and politics causes well-being in the leftist sample to rise - an effect that we do not observe in the right-wing sample. ${ }^{14}$

Another pattern emerges when comparing results across income. In general, men with low income appear to be (socially) excluded from the benefits of diminishing discrimination compared with (a) men earning middle incomes or (b) women with low incomes. Social

\footnotetext{
${ }^{14}$ In case of the effect of discrimination in business of women, the significance level in the rightist sample is much lower as compared to that in the leftist sample. An exception is gender equality in politics which appears more beneficial for rather conservative women.
} 
exclusion might be caused by tight budget constraints leading to non-participation and marginalization, as men with low income do not benefit from more gender equality in politics as compared to richer men or equally poor women. Furthermore, men with low income are excluded from the benefits through less discrimination in the labor market that are observed for women with low income. These results are consistent with an inflow of female workers compressing wages of all low-skilled workers alike, although it still yields some positive benefits in particular to women with low income. Moreover, the same observation holds for less discrimination in social relations that is only conducive to women with low income. This finding is in line with our expectation that strengthening women's position within the household might alter the bargaining power within the household to her advantage. ${ }^{15}$

Overall, our results show that no simple conclusions can be drawn from the study of the effects of gender discrimination on subjective well-being. The effects are heterogeneous across groups in society and across different spheres. Our results are more in line with hypothesis 2 than hypothesis 1 , as inequality seems to be detrimental to the well-being of both men and women. Still, the effect is more pronounced on women, at least partly supporting hypothesis 1 . Hypothesis 3 expected the effect of gender inequality to be absent on people with high income, which is partly confirmed. However, according to hypothesis 4 , gender equality is particularly beneficial for people with low income. We find little evidence for this. Hypothesis 5, finally, stressed the importance of gender equality for people on the political left, in particular. We found strong evidence in favor of this hypothesis.

\section{Conclusions}

Improvements in gender equality are considered to be among the major social achievements in human history. Still, it remains an open question whether women have actually benefited from equality. Equally open is the question how the happiness of men has been affected. Does the direction or strength of the impact of equality depend on financial circumstances or the political orientations of individuals? These are the questions this study analyzed, based on cross-sectional analysis of more than 60'000 individuals living in a maximum of 66 countries. Our measure of gender equality, taken from the CIRI database, allows us to observe the impact of past levels as well as changes in discriminatory practices over the last 20 years.

Our results show that the effect of gender discrimination on life satisfaction indeed varies between men and women, and also across different income and ideological groups. Focusing on the broad picture, our results reveal that in particular discrimination in politics is

\footnotetext{
15 Another example pertains to discrimination in the economic sphere, where positive path dependence effects are observable for women with middle and high incomes, but not for corresponding men.
} 
important to life satisfaction: overall, both men and women are more satisfied with their lives with increasing equality in participation possibilities in politics. Disaggregated analysis suggests that our results for men are driven by the effect of equality on men with middle and high income, and those on the political left. To the contrary, women are more satisfied with increasing political equality independent of income and political ideology. In contrast, changing equality in economic and social matters over the last decades does overall not affect life satisfaction. However, women are more satisfied with their lives when there has been less discrimination in the economy 20 years ago. Hence, according to our results past inequality in the economy equally matters to well-being as changes in discrimination over time, indicating strong path dependence of individuals' occupational and other economic choices. In contrast, changes in gender equality in politics over time seem to be more important to well-being than past levels. Equality in the social sphere does not matter for well-being at all.

More differential impacts arise when we split the samples of men and women by income or political orientation. In general, people with low income profit differently than those with high- and middle income, while less discrimination often affects persons with a leftist orientation differently from the average right-wing person. However, while the results for our various sub-groups show no clear pattern, we find considerable support for some of our hypotheses. In particular, our data do confirm that (a change in) gender inequality affects rich people less, particularly women with high income. On the other hand, people with low income gain less or nothing from social progress, potentially because the household budget constraint is tight. We also find some support for the hypothesis that inequality is more important for people on the political left compared to those on the right.

However, our results show the need to stress the importance of a simple insight: that gender equality cannot be treated as one unitary phenomenon. The findings in this paper show that some measures of gender inequality are significantly associated with well-being, while others do not appear to impact life satisfaction. As such, it must be realized that gender inequality is always measured from an outside perspective, using indicators and benchmarks that are neutral to culture or history. However, it might well be that women's assessment of subjective discrimination is a completely different one. The internalization of stereotypes, for example, may help in mitigating the negative impacts of discrimination (cf. Schmitt et al., 2002, Foster et al., 2004). In order to obtain a more complete picture, it is therefore arguably important to take into account the perceived degree of gender equality as well as factual social reality even if - and perhaps in particular because of - those evaluations may not appear consistent. 


\section{References}

Becker, Gary S. (1957/1971), The Economic of Discrimination, $2^{\text {nd }}$ edition 1971, Chicago: University of Chicago Press.

Bjørnskov, C., A. Dreher and J.A.V. Fischer (2007). The Bigger the Better? Evidence of the Effect of Government Size on Life Satisfaction Around the World. Public Choice 130, pp. 267-292.

Bjørnskov, C., A. Dreher, J.A.V. Fischer (in press). Cross-Country Determinants of Life Satisfaction. Comparing Different Determinants across Groups in Society. Forthcoming in Social Choice and Welfare.

Blankenship, K. M. (1993). Bringing Gender and Race In: U.S. Employment Discrimination Policy. Gender \& Society 7, pp. 204-226.

Browne, J., and M. Stears (2005). Capabilities, resources and systematic injustice: a case of gender inequality. Politics, Philosophy \& Economics, 4, pp. 355-373.

Busse, M. and C. Spielmann (2006). Gender Inequality and Trade. Review of International Economics 14, pp. 362-79.

Buswell, C. and Jenkins, S. (1994). Equal Opportunities Policies, Employment and Patriarchy. Gender, Work and Organization, 1, pp. 83-93.

Choi, J. Y and S.-H. Lee (2006). Does prenatal care increase access to child immunization? Gender bias among children in India. Social Science \& Medicine 63, pp. 107-117.

Cingranelli, D.L. and D.L. Richards (2004). Cingranelli-Richards (CIRI) Human Rights Database, Coder Manual Version 8.01.04 http://ciri.binghamton.edu/documentation/ web_version_7_31_04_ciri_coding_guide.pdf (06.Nov.2006).

Dorn, D., J.A.V. Fischer, G. Kirchgässner and A. Sousa-Poza: (2006). Is it Culture or Democracy? The Impact of Democracy and Culture on Happiness, Social Indicators Research, DOI: 10.1007/s11205-006-9048-4.

Dorn, D., J.A.V. Fischer, G. Kirchgässner and A. Sousa-Poza: (in press). Direct Democracy and Life Satisfaction Revisited - New Evidence for Switzerland. forthcoming in Journal of Happiness Studies.

Ferrer-i-Carbonell, I. (2005). Income and Well-Being: An Empirical Analysis of the Comparison Income Effect. Journal of Public Economics 89, pp. 997-1019.

Fischer, J.A.V. and A. Rodríguez-Andrés (2007). Political institutions and suicide: A regional analysis of Switzerland, paper presented at the Royal Economic Society Conference 2007. 
Foster, M.D., S. Arnt and J. Honkola (2004). When the Advantaged Become Disadvantaged: Men's and Women's Actions Against Gender Discrimination, Sex Roles, 50, pp. 27-36.

Frey, B.S. and A. Stutzer (2000). Maximizing Happiness? German Economic Review, 1, pp. 145-167.

Goldin, C. (2006). The Quiet Revolution That Transformed Women's Employment, Education, and Family. American Economic Review 96, pp. 1-21.

Goto, M. (2006). The lives and roles of women of various classes in the $I E$ of late Medieval Japan. International Journal of Asian Studies 2, pp. 183-210.

Hakim, C. (1991). Grateful slaves and self-made women: fact and fantasy in women's work orientation. European Sociological Review 7, pp. 101-122.

Huntington, S. P. (1993). The Clash of Civilizations. Foreign Affairs 72, pp. 22-49.

Irwin, F.W. (1944). The Realism of Expectations. Psychological Review 51, pp. 120-126.

Kim, M. (1989). Gender Bias in Compensation Structures: A Case Study of Its Historical Basis and Persistence. Journal of Social Issues 45, pp. 39-49.

Lykken, D. and A. Tellegen. (1996). Happiness is a Stochastic Phenomenon. Psychological Science 7, pp. 186-189.

Mertz, N.T. (2006). The Promise of Title IX: Longitudinal Study of Gender in Urban School Administration, 1972 to 2002. Urban Education 41, pp. 544-559.

Moulton, B. (1990). An Illustration of a Pitfall in Estimating the Effects of Aggregate Variables on Micro Units, The Review of Economics and Statistics 72, pp. 434-438.

Munshi, K. and M. Rosenzweig (2006). Traditional Institutions Meet the Modern World: Caste, Gender, and Schooling Choice in a Globalizing Economy. American Economic Review 96, pp. 1225-1252.

Neumark, D. and M. McLennan. (1995). Sex discrimination and women's labor market outcomes. Journal of Human Resources 30(4), pp. 713-740.

Neumark, D. and W.A. Stock. (2006). The labor market effects of sex and race discrimination laws. Economic Inquiry 44, pp 385-419.

Patessio. M. (2006). The Creation of Public Spaces by Women in the Early Meiji Period and the Tokyo Fujin Kyofukai. International Journal of Asian Studies 3, pp. 155-182.

Pitt, M.M., S.R. Khandker and J. Cartwright. (2006). Empowering Women with Micro Finance: Evidence from Bangladesh. Economic Development and Cultural Change 54, pp. 791-831.

Rodriguez, S.F., T.R. Curry and G. Lee (2006). Gender Differences in Criminal Sentencing: Do Effects Vary across Violent, Property, and Drug Offenses? Social Science 
Quarterly 87, pp. 318-39.

Schilt, K. (2006). Just one of the guys? How transmen make gender visible at work. Gender and Society 20, pp. 465-490.

Schmitt, M, T., N.R. Branscombe, D. Kobrynowicz, and S. Owen (2002). Perceiving discrimination against one's gender group has different implications for well-being in women and men. Personality and Social Psychology Bulletin 28, pp. 197-210.

Sen, A. (1999). Development as Freedom. New York: Random House.

Shah, S. (2006). Sexual Division of Labor in Adam Smith's Work. Journal of the History of Economic Thought 28, pp. 221-241.

Siegel, M. J. (2006). Measuring the effect of husband's health on wife's labor supply. Health Economics 15, pp. 579-601.

Stanley, T.D. and S.B. Jarrell (1998). Gender wage discrimination bias? A meta-regression analysis. Journal of Human Resources 33(4), pp. 947-973.

Theodossiou, I. (1998). The Effects of Low-Pay and Unemployment on Psychological WellBeing: A Logistic Regression Approach. Journal of Health Economics 17, pp. 85-104.

Turner, L.J., S. Danziger and K.S. Seefeldt (2006). Failing the Transition from Welfare to Work: Women Chronically Disconnected from Employment and Cash Welfare. Social Science Quarterly 87, pp. 227-249.

Wellington, A.J. (2006). Self-employment: the new solution for balancing family and career? Labour Economics 13, pp. 357-386. 
Table 1: Changes in equality of women in the economy

\begin{tabular}{lrrr}
\hline & \multicolumn{1}{l}{ all } & \multicolumn{1}{l}{ male } & \multicolumn{1}{c}{ female } \\
\hline Change 1980 - 2000 & & & \\
& 0.076 & 0.046 & 0.103 \\
Marginal effect & {$[1.00]$} & {$[0.58]$} & {$[1.40]$} \\
Level 1980 & 0.014 & 0.008 & 0.020 \\
& 0.112 & 0.054 & $0.169^{\star *}$ \\
Marginal effect & {$[1.37]$} & {$[0.65]$} & {$[2.04]$} \\
Observations & 0.020 & 0.010 & $0.032^{* *}$ \\
Countries & 59971 & 30411 & 29560 \\
Pseudo R2 & 62 & 62 & 62 \\
\hline
\end{tabular}

Notes: z-statistics in brackets. Variables reported in Appendix Table A1 included in all regressions.

Table 2: Changes in equality of women in politics

\begin{tabular}{lrrr}
\hline & \multicolumn{1}{c}{ all } & \multicolumn{1}{c}{ male } & \multicolumn{1}{c}{ female } \\
\hline & & & \\
\hline Change 1980 - 2000 & $0.195^{\star \star *}$ & $0.135^{\star *}$ & $0.253^{\star \star *}$ \\
& {$[2.94]$} & {$[2.08]$} & {$[3.35]$} \\
Marginal effect & $0.035^{* *}$ & $0.023^{* *}$ & $0.048^{* * *}$ \\
Level 1980 & $0.109^{* *}$ & 0.049 & $0.169^{* *}$ \\
& {$[1.78]$} & {$[0.80]$} & {$[2.44]$} \\
Marginal effect & $0.020^{*}$ & 0.010 & $0.032^{* *}$ \\
\hline Observations & 60446 & 30693 & 29753 \\
Countries & 63 & 63 & 63 \\
Pseudo R2 & 0.0604 & 0.0648 & 0.058 \\
\hline
\end{tabular}

Notes: z-statistics in brackets. Variables reported in Appendix Table A1 included in all regressions.

Table 3: Changes in equality of women in society

\begin{tabular}{lrrr}
\hline & \multicolumn{1}{l}{ all } & \multicolumn{1}{c}{ male } & female \\
\hline Change 1980 - 2000 & 0.007 & -0.027 & 0.046 \\
& {$[0.14]$} & {$[0.49]$} & {$[0.82]$} \\
Marginal effect & 0.001 & -0.005 & 0.008 \\
Level 1980 & 0.036 & -0.019 & 0.097 \\
& {$[0.52]$} & {$[0.27]$} & {$[1.30]$} \\
Marginal effect & 0.006 & -0.003 & 0.018 \\
\hline Observations & 58660 & 29786 & 28874 \\
Countries & 61 & 61 & 61 \\
Pseudo R2 & 0.0599 & 0.0644 & 0.0576 \\
\hline
\end{tabular}

Notes: z-statistics in brackets. Variables reported in Appendix Table A1 included in all regressions. 
Table 4: Changes in equality of women in the economy (men)

\begin{tabular}{lrrrrr}
\hline & left & right & income low & income mid & income high \\
\hline Change 1980 - 2000 & 0.086 & 0.003 & 0.054 & 0.031 & 0.059 \\
& {$[1.13]$} & {$[0.04]$} & {$[0.50]$} & {$[0.39]$} & {$[0.65]$} \\
Marginal effect & 0.013 & 0.001 & 0.009 & 0.005 & 0.011 \\
Level 1980 & $0.156^{*}$ & -0.036 & 0.019 & 0.109 & 0.055 \\
& {$[1.83]$} & {$[0.40]$} & {$[0.15]$} & {$[1.25]$} & {$[0.55]$} \\
Marginal effect & 0.024 & -0.007 & 0.003 & 0.018 & 0.010 \\
\hline Observations & 16424 & 13987 & 9178 & 11208 & 10025 \\
Countries & 62 & 62 & 62 & 62 & 62 \\
Pseudo R2 & 0.0691 & 0.0589 & 0.0568 & 0.0693 & 0.054 \\
\hline
\end{tabular}

Notes: z-statistics in brackets. Variables reported in Appendix Table A1 included in all regressions.

Table 5: Changes in equality of women in the economy (women)

\begin{tabular}{lrrrrr}
\hline & left & right & income low & income mid & income high \\
\hline & & & & & \\
\hline Change 1980 - 2000 & 0.089 & 0.123 & 0.115 & 0.118 & 0.054 \\
& {$[1.13]$} & {$[1.64]$} & {$[1.37]$} & {$[1.32]$} & {$[0.73]$} \\
Marginal effect & 0.015 & 0.027 & 0.021 & 0.022 & 0.011 \\
Level 1980 & $0.189^{\star *}$ & $0.147^{*}$ & $0.224^{\star *}$ & $0.176^{*}$ & 0.11 \\
& {$[2.15]$} & {$[1.72]$} & {$[2.25]$} & {$[1.78]$} & {$[1.15]$} \\
Marginal effect & $0.032^{\star *}$ & $0.032^{*}$ & $0.041^{\star *}$ & $0.032^{*}$ & 0.023 \\
\hline Observations & 16551 & 13009 & 10324 & 10532 & 8704 \\
Countries & 62 & 62 & 62 & 62 & 62 \\
Pseudo R2 & 0.0626 & 0.0496 & 0.0532 & 0.0584 & 0.0507 \\
\hline
\end{tabular}

Notes: z-statistics in brackets. Variables reported in Appendix Table A1 included in all regressions.

Table 6: Changes in equality of women in politics (men)

\begin{tabular}{lrrrrr}
\hline & \multicolumn{1}{c}{ left } & right & income low & income mid & income high \\
\hline & & & & & \\
\hline Change 1980 - 2000 & $0.156^{\star \star}$ & 0.125 & -0.001 & $0.153^{\star}$ & $0.276^{\star \star \star}$ \\
& {$[2.40]$} & {$[1.60]$} & {$[0.01]$} & {$[1.77]$} & {$[2.92]$} \\
Marginal effect & $0.024^{\star *}$ & 0.024 & -0.000 & $0.026^{*}$ & $0.051^{* \star \star}$ \\
Level 1980 & 0.068 & 0.045 & -0.118 & 0.072 & 0.138 \\
& {$[1.12]$} & {$[0.55]$} & {$[1.61]$} & {$[0.89]$} & {$[1.43]$} \\
Marginal effect & 0.011 & 0.009 & -0.020 & 0.012 & 0.026 \\
\hline Observations & 16582 & 14111 & 9282 & 11270 & 10141 \\
Countries & 63 & 63 & 63 & 63 & 63 \\
Pseudo R2 & 0.0689 & 0.0589 & 0.0561 & 0.0696 & 0.0556 \\
\hline
\end{tabular}

Notes: z-statistics in brackets. Variables reported in Appendix Table A1 included in all regressions. 
Table 7: Changes in equality of women in politics (women)

\begin{tabular}{|c|c|c|c|c|c|}
\hline & left & right & income low & income mid & Income high \\
\hline Chan & $\begin{array}{r}0.237^{\star \star \star} \\
{[3.03]}\end{array}$ & $\begin{array}{r}0.287^{\star * \star} \\
{[3.58]}\end{array}$ & $\begin{array}{r}0.205^{\star \star} \\
{[2.39]}\end{array}$ & $\begin{array}{r}0.316^{* * *} \\
{[3.36]}\end{array}$ & $\begin{array}{r}0.278^{\star \star \star} \\
{[3.27]}\end{array}$ \\
\hline Marginal effect & $0.039^{\star * *}$ & $0.062^{\star \star *}$ & $0.038^{\star *}$ & $0.057^{\star \star \star}$ & $0.057^{\star \star *}$ \\
\hline Leve & $\begin{array}{r}0.166^{* *} \\
{[2.36]}\end{array}$ & $\begin{array}{r}0.187^{* *} \\
{[2.40]}\end{array}$ & $\begin{array}{c}0.137^{*} \\
{[1.66]}\end{array}$ & $\begin{array}{r}0.190^{\star *} \\
{[2.02]}\end{array}$ & $\begin{array}{l}0.127 \\
{[1.54]}\end{array}$ \\
\hline Marginal effect & $0.028^{\star *}$ & $0.040^{* *}$ & 0.025 & $0.0343^{*}$ & 0.026 \\
\hline Observations & 16663 & 13090 & 10401 & 10579 & 8773 \\
\hline Countries & 63 & 63 & 63 & 63 & 63 \\
\hline Pseudo R2 & 0.0628 & 0.0497 & 0.0528 & 0.0591 & 0.0519 \\
\hline
\end{tabular}

Notes: z-statistics in brackets. Variables reported in Appendix Table A1 included in all regressions.

Table 8: Changes in equality of women in society (men)

\begin{tabular}{lrrrrr}
\hline & left & \multicolumn{1}{l}{ right } & income low & income mid & income high \\
\hline & \multicolumn{5}{c}{} \\
\hline Change 1980 - 2000 & 0.026 & -0.080 & -0.046 & -0.023 & -0.041 \\
& {$[0.53]$} & {$[1.17]$} & {$[0.72]$} & {$[0.37]$} & {$[0.47]$} \\
Marginal effect & 0.004 & -0.015 & -0.008 & -0.004 & -0.007 \\
Level 1980 & 0.069 & -0.096 & -0.068 & 0.03 & -0.024 \\
& {$[1.04]$} & {$[1.15]$} & {$[0.79]$} & {$[0.37]$} & {$[0.23]$} \\
Marginal effect & 0.010 & -0.018 & -0.011 & 0.005 & -0.004 \\
\hline Observations & 16096 & 13690 & 9054 & 10924 & 9808 \\
Countries & 61 & 61 & 61 & 61 & 61 \\
Pseudo R2 & 0.0684 & 0.0587 & 0.0555 & 0.0698 & 0.0542 \\
\hline
\end{tabular}

Notes: z-statistics in brackets. Variables reported in Appendix Table A1 included in all regressions.

Table 9: Changes in equality of women in society (women)

\begin{tabular}{lrrrrr}
\hline & left & right & income low & income mid & income high \\
\hline & \multicolumn{7}{c}{} \\
\hline Change 1980 - 2000 & 0.046 & 0.042 & 0.067 & 0.027 & 0.012 \\
& {$[0.77]$} & {$[0.68]$} & {$[1.07]$} & {$[0.43]$} & {$[0.17]$} \\
Marginal effect & 0.007 & 0.009 & 0.012 & 0.005 & 0.003 \\
Level 1980 & 0.094 & 0.091 & $0.176^{\star *}$ & 0.092 & 0.012 \\
& {$[1.25]$} & {$[1.09]$} & {$[2.22]$} & {$[1.02]$} & {$[0.13]$} \\
Marginal effect & 0.015 & 0.019 & $0.032^{\star \star}$ & 0.016 & 0.002 \\
\hline Observations & 16190 & 12684 & 10163 & 10236 & 8475 \\
Countries & 61 & 61 & 61 & 61 & 61 \\
Pseudo R2 & 0.0626 & 0.049 & 0.053 & 0.0586 & 0.0508 \\
\hline
\end{tabular}

Notes: z-statistics in brackets. Variables reported in Appendix Table A1 included in all regressions. 


\section{Appendix}

Table A1: Women's political rights

\begin{tabular}{|l|l|}
\hline & Women's political rights \\
\hline 0 & $\begin{array}{l}\text { None of women's political rights are guaranteed by law. There are laws that } \\
\text { completely restrict the participation of women in the political process. }\end{array}$ \\
\hline 1 & $\begin{array}{l}\text { Political equality is guaranteed by law. However, there are significant limitations in } \\
\text { practice. Women hold less than five percent of seats in the national legislature and in } \\
\text { other high-ranking government positions }\end{array}$ \\
\hline 2 & $\begin{array}{l}\text { Political equality is guaranteed by law. Women hold more than five percent but less } \\
\text { than thirty percent of seats in the national legislature and/or in other high-ranking } \\
\text { government positions }\end{array}$ \\
\hline 3 & $\begin{array}{l}\text { Political equality is guaranteed by law and in practice. Women hold more than thirty } \\
\text { percent of seats in the national legislature and/or in other high-ranking government } \\
\text { positions }\end{array}$ \\
\hline
\end{tabular}

Source: Cingranelli and Richards (2004)

Table A2: Women's economic rights

\begin{tabular}{|l|l|}
\hline & Women's economic rights \\
\hline 0 & $\begin{array}{l}\text { There are no economic rights for women under law and systematic discrimination } \\
\text { based on sex may be built into the law. The government tolerates a high level of } \\
\text { discrimination against women. }\end{array}$ \\
\hline 1 & $\begin{array}{l}\text { There are some economic rights for women under law. However, in practice, the } \\
\text { government DOES NOT enforce the laws effectively or enforcement of laws is } \\
\text { weak. The government tolerates a moderate level of discrimination against women. }\end{array}$ \\
\hline 2 & $\begin{array}{l}\text { There are some economic rights for women under law. In practice, the government } \\
\text { DOES enforce these laws effectively. However, the government still tolerates a low } \\
\text { level of discrimination against women. }\end{array}$ \\
\hline 3 & $\begin{array}{l}\text { All or nearly all of women's economic rights are guaranteed by law. In practice, the } \\
\text { government fully and vigorously enforces these laws. The government tolerates } \\
\text { none or almost no discrimination against women }\end{array}$ \\
\hline
\end{tabular}

Source: Cingranelli and Richards (2004)

Table A3: Women's social rights

\begin{tabular}{|l|l|}
\hline & Women's social rights \\
\hline 0 & $\begin{array}{l}\text { There are no social rights for women under law and systematic discrimination based } \\
\text { on sex may be built into the law. The government tolerates a high level of } \\
\text { discrimination against women. }\end{array}$ \\
\hline 1 & $\begin{array}{l}\text { There are some social rights for women under law. However, in practice, the } \\
\text { government DOES NOT enforce these laws effectively or enforcement of laws is } \\
\text { weak. The government tolerates a moderate level of discrimination against women.. }\end{array}$ \\
\hline 2 & $\begin{array}{l}\text { There are some social rights for women under law. In practice, the government } \\
\text { DOES enforce these laws effectively. However, the government still tolerates a low } \\
\text { level of discrimination against women.. }\end{array}$ \\
\hline 3 & $\begin{array}{l}\text { All or nearly all of women's social rights are guaranteed by law. In practice, the } \\
\text { government fully and vigorously enforces these laws. The government tolerates } \\
\text { none of almost no discrimination against women. }\end{array}$ \\
\hline
\end{tabular}

Source: Cingranelli and Richards (2004) 


\section{Appendix}

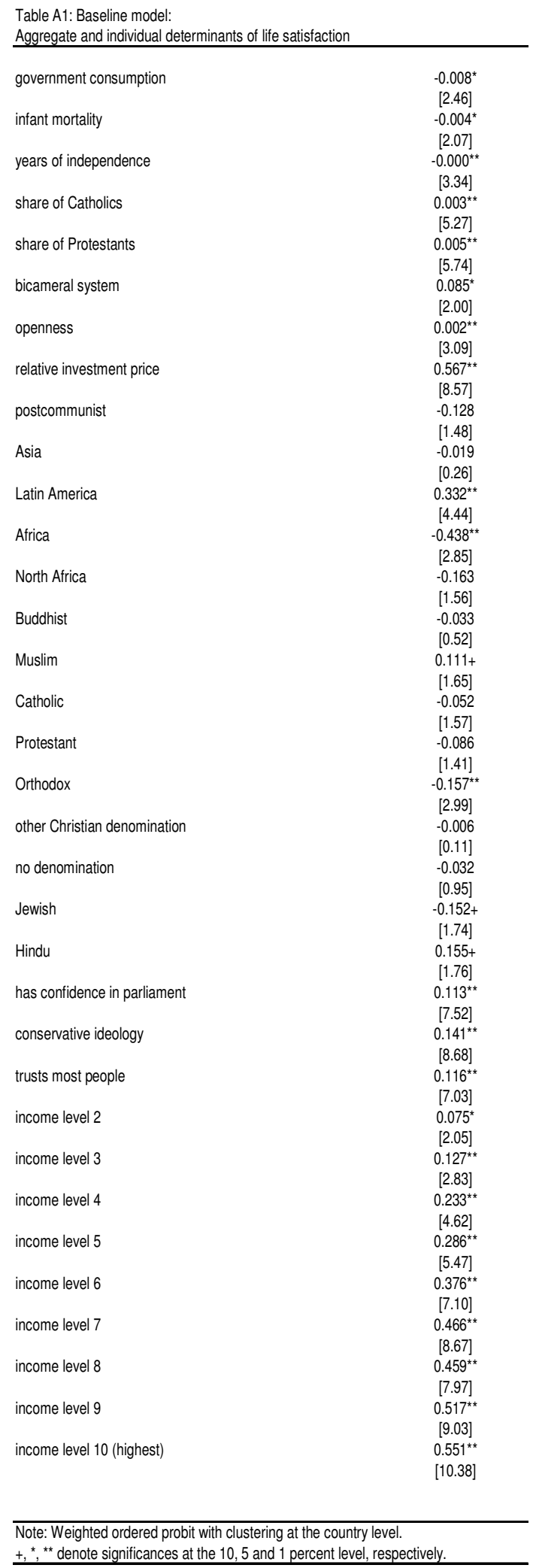

Table A1: Baseline model:

$\underline{\text { Aggregate and individual determinants of life satisfaction (cont.) }}$

age $25-34$

-0.265
$[9.24]$

age 45 - 54

$\begin{array}{lr} & {[10.17} \\ \text { age } 55-64 & -0.192^{*}\end{array}$

age $>64$

male $\quad-0.029$

$[1.70]$

completed primary education $-\frac{0.008}{-10.19]}$

incomplete sec. edu., technical focus

$[1.06]$

$[0.03$

incomplete sec. edu, university preparation $\quad 0.005$

complete sec. edu., university preparation $\quad 0.022$

lower-level tertiary education $\quad[0.45]$

$[0.01]$

upper-level tertiary education $\quad 0.071$

$[1.43$

$-0.008$

single male $\quad-0.07$

[1.63]

$\begin{array}{ll} & {[6.98]} \\ \text { cohabiting } & 0.177^{* *}\end{array}$

$[2.75]$

has had 1 child $\quad-0.02$

has had 2 children $\quad 0.004$

has had 3 or more children $\quad 0.016$

selfemployed $\quad[0.68]$

$[1.13]$

housewife $\quad 0.008$

$[0.25$

$\begin{array}{lr} & {[1.44]} \\ \text { other } & -0.121^{\text {** }}\end{array}$

[3.03]

$\begin{array}{ll}\text { student } & 0.03\end{array}$

$\begin{array}{cc} & {[1.14]} \\ \text { unemployed } & -0.272^{* *}\end{array}$

[8.30]

service participation: > once a week $\quad 0.200$

service participation: once a week $\quad 0.130^{\star}$

$\begin{array}{lc} & {[4.12]} \\ \text { service participation: once a month } & 0.078^{* *}\end{array}$

service participation: on common holy days

$[2.56]$

service participation: on specific holy days $\quad 0.051$

service participation: once a year $\quad[1.79]$

$[0.73]$

service participation: less than once a year $\quad-0.027$

believes in superior being $\quad[1.19$

$[2.13]$

Observations 6229

Number of countries $\quad 66$

\begin{tabular}{ll} 
adj. Pseudo R2 & 0.0607 \\
\hline
\end{tabular} 